\title{
ANORECTAL MALFORMATIONS- 12 YEARS STUDY
}

\author{
Chanda Bhaskara Rao1, G. Hasanthi², J. S. Kishore ${ }^{3}$, Pavan Kumar Nimmala4, R. Suman ${ }^{5}$, Bhavana Chanda ${ }^{6}$
}

${ }^{1}$ Associate Professor, Department of Paediatric Surgery, Government General Hospital and Guntur Medical College, Guntur, A. P. ${ }^{2}$ Assistant Professor, Department of Paediatric Surgery, Government General Hospital and Guntur Medical College, Guntur, A. P. ${ }_{3}^{3}$ Senior Resident, Department of Paediatric Surgery, Government General Hospital and Guntur Medical College, Guntur, A. P. ${ }^{4}$ Senior Resident, Department of Paediatric Surgery, Government General Hospital and Guntur Medical College, Guntur, A. P. ${ }^{5}$ Postgraduate Student, Department of Paediatric Surgery, Government General Hospital and Guntur Medical College, Guntur, A. P. 6Junior Resident, Department of Paediatric Surgery, Government General Hospital and Guntur Medical College, Guntur, A. P.

\section{BACKGROUND}

ABSTRACT

Anorectal malformations are among the more frequent congenital anomalies encountered in paediatric surgery with an estimated incidence ranging between 1 in 3500 and 1 in 5000 live births. Most cases are diagnosed in the early neonatal period. There is a wide spectrum of abnormalities ranging from low anomalies with perineal fistula having simple management to high anomalies with complex management.

It is a retrospective study of anorectal malformations in our Institute during July 2005 to July 2017 from our department over the 12-year period and the aim of the study is to analyse type of anomalies, procedures done and outcome in our settings. Study Design- Retrospective record based study.

\section{MATERIALS AND METHODS}

We collected data from our records from July 2005 to July 2017, from our Paediatric Surgery Department over 12-year period. A total of 690 patients were analysed from our records; 478 were male children, 212 were female children from Government General Hospital and Guntur Medical College, Guntur, Andhra Pradesh.

\section{RESULTS}

Out of 690, 478 were male (69.3\%) and 212 (30.7\%) were female; 191 males had low anomaly (39.9\%) and 18 female had low anomaly (8.49\%). Total 209 patients of both male and female sex had low anomalies (30.2\%). All low anomalies were treated by anoplasty. A total of 481 children of both sex had high or intermediate anomalies (69.8\%), managed by either staged procedures or single stage repair at appropriate weight gain.

\section{CONCLUSION}

Most of the low anomalies and majority high anomalies have reasonably acceptable result with achievement of complete fecal and urinary continence with good quality of life, which is long-term goal of these malformations.

\section{KEYWORDS}

Anorectal Malformations, Imperforate Anus, Colostomy, Anal Transposition, Vestibular Anus, PSARP, Rectourethral Fistula.

HOW TO CITE THIS ARTICLE: Rao CB, Hasanthi G, Kishore JS, et al. Anorectal malformations- 12 years study. J. Evolution Med. Dent. Sci. 2017;6(92):6538-6544, DOI: 10.14260/jemds/2017/1418

\section{BACKGROUND}

Anorectal malformations (ARMs) or an imperforate anus are birth defects in which the anus and rectumare malformed. Anorectal malformations are among the more frequent congenital anomalies encountered in paediatric surgery with an estimated incidence ranging between 1 in 3500 and 1 in 5000 live births.(1) Antenatal diagnosis of an isolated anorectal malformations is rare.(2) Most cases are diagnosed in the early neonatal period. There is a wide spectrum of presentation ranging from low anomalies with perineal fistula having simple management to high anomalies with complex management. (3)

'Financial or Other Competing Interest': None.

Submission 23-10-2017, Peer Review 16-11-2017,

Acceptance 22-11-2017, Published 04-12-2017.

Corresponding Author:

Dr. G. Hasanthi,

C/o. Dr. Chanda Bhaskara Rao,

\#26-1-96, 4A, B. G. Arcade,

Nagarampalem Main Road,

Guntur-522004, Andhra Pradesh.

E-mail: chandabhavana@rediffmail.com

DOI: $10.14260 / \mathrm{jemds} / 2017 / 1418$
ARMs are a spectrum of different congenital anomalies in males and females that varies from fairly minor lesions to complex anomalies. The cause of ARMs is unknown. The genetic basis of these anomalies is very complex, because of their anatomical variability. In $8 \%$ of patients, genetic factors are clearly associated with ARMs. Anorectal malformation in Currarino syndrome represents the only association, for which the gene HLXB9 has been identified.(4) Since the early era of its management, its treatment has gone through an enormous phase of evolution leading from gloomy outcome in the past to nearly all survival in the modern era. The management of ARM has moved forward from classical procedures to PSARP to minimal invasive procedures. But still the faecal and urinary incontinence can occur even with an excellent anatomic repair, mainly due to associated problems. There has been a great shift in approach to these patients, which involves holistic approach to the syndrome of anorectal malformations with a long-term goal of achievement of complete faecal and urinary continence with excellent quality of life. 


\section{Embryology}

The embryogenesis of these malformations remains unclear. (5) The rectum and anus are believed to develop from the dorsal portion of the hindgut or cloacal cavity when lateral ingrowth of the mesenchyme forms the urorectal septum in the midline. This septum separates the rectum and anal canal dorsally from the bladder and urethra. The cloacal duct is a small communication between the 2 portions of the hindgut. Down growth of the urorectal septum is believed to close this duct by 7 weeks' gestation.(6) During this time, the ventral urogenital portion acquires an external opening; the dorsal anal membrane opens later. The anus develops by a fusion of the anal tubercles and an external invagination known as the proctodeum, which deepens toward the rectum but is separated from it by the anal membrane. This separating membrane should disintegrate at 8 weeks' gestation.

Interference with anorectal structure development at varying stages leads to various anomalies, ranging from anal stenosis, incomplete rupture of the anal membrane or anal agenesis to complete failure of the upper portion of the cloaca to descend and failure of the proctodeum to invaginate. Continued communication between the urogenital tract and rectal portions of the cloacal plate causes rectourethral fistulas or rectovestibular fistulas. The external anal sphincter derived from exterior mesoderm is usually present, but has varying degrees of formation ranging from good muscle (perineal or vestibular fistula) to virtually no muscle (complex long-common-channel cloaca, prostatic or bladderneck fistula). Understanding the true anatomy is helpful to prevent damage to important structures during surgical repair and to preserve the best potential for bowel control. Anatomic visualisation has allowed surgeons to eliminate many previous misconceptions.

\section{Anatomy}

The levator ani muscle lies in a plane between the symphysis pubis and the coccyx (PC line on invertogram). This muscle comprises of ileococcygeus and pubococcygeus including puborectalis. The puborectalis forms the most medial part of the levator hammock. The external anal sphincter (EAS) has three components which are superficial, subcutaneous and deep sphincter muscles. The deep fibres of the EAS blend imperceptibly into the inferior portion of the puborectalis. These anatomically inseparable muscle entities function invivo as a single coherent unit and all are important in normal continence.

In 1953, Stephens described this procedure with specific emphasis on preservation of the puborectalis muscle. In 1972, Pena paid particular attention to puborectalis. He considers it to be a striated muscle complex and no separate puborectalis sling.

Anorectal and urogenital malformations are rarely fatal, although some associated anomalies (cardiac, renal) can be life threatening. Intestinal perforation or postoperative septic complications in a newborn with imperforate anus can result in mortality or severe morbidity.

\section{Presentation}

No known sex predilection has been reported. Most children with an anorectal malformation are identified upon routine newborn physical examination. Delayed presentation is often the result of incomplete initial examination. Newborn anorectal and urogenital examination can be technically challenging and makes many practitioners uncomfortable. Subtle malformations such as those in some children with perineal fistula that may look normal to the casual glance may be present for months or years after birth when the child presents to a primary care provider for constipation or urinary tract infection and appears to have a small perineal body upon physical examination. Anorectal malformations in females with a normal appearing anus who have absent vagina or persistent urogenital sinus may go undiagnosed for years, because of examiner's reluctance to separate the labia during physical examination. These malformations can be discovered upon evaluation for urinary tract infection or primary amenorrhea. Prenatal ultrasonography examination findings are often normal. Newborns with imperforate anus are usually identified upon the first physical examination. Malformations in newborns that are missed upon initial examination are often discovered within 24 hours when the newborn is observed to have distention and has failed to pass meconium and a more thorough examination is performed.

\section{Physical Examination}

Examination of abdomen, genitals, rectum and lower spine. The abdomen should be palpated for masses which may include a dilated kidney, bladder, hydrocolpos, ectopic kidney, duplication or other cystic structure.

In males, the testicles must be palpated in the scrotum. The perineum is then examined. Perineal fistulas are diagnosed upon discovery of openings on the perineum, meconium or mucus in a small strip running up into the scrotal median raphe, a perineal groove or a bucket-handle malformation in the anal dimple skin. If no opening is present urine is obtained for study and the child is observed for 24 hours.

In females, a perineal fistula can be directly identified as a small opening on the perineum. If none is present, the labia are separated to search for a vestibular fistula. A fourchette fistula is a type of vestibular fistula that straddles the spectrum of malformation between perineal and vestibular. It is characterised by wet mucosa of the vestibule anteriorly and a dry anoderm posteriorly at the junction of the vestibule and perineum, classic appearance of a girl with a cloacal malformation with a single perineal orifice. The genitals appear quite short, which is a finding consistent with cloaca. If the child has a normal urethra and no vestibular fistula, she may have imperforate anus without fistula. If she appears to have trisomy 21, the likelihood increases that she does not have a fistula. Girls with normal urethra and no visible fistula are observed for 24 hours to allow a perineal fistula to present before operation is required. This waiting period is beneficial in differentiating between children with perineal fistula, who may be effectively treated using only a minimal anoplasty from those who require colostomy with further evaluation using distal cologram. If the child has a normal urethra and no vestibular fistula, she may have imperforate anus without fistula. If she appears to have Down syndrome, the likelihood increases that she does not have a fistula.

\section{Associated Anomalies}

Imperforate anus is associated with an increased incidence of some specific anomalies as well, together being called 
the VACTERL association(7): V- Vertebral anomalies, A- Anal atresia, C-Cardiovascular anomalies, TE- Tracheoesophageal fistula, R- Renal or radial anomalies, L- Limb defects. Look for associated malformations. Cardiovascular malformations occur in $12 \%-22 \%$ of patients. The most common lesions are tetralogy of Fallot and ventricular septal defects. Transposition of the great arteries and hypoplastic left heart syndrome have been reported but are rare.

Many GI malformations have been described in association with imperforate anus. As many as $10 \%$ of patients have tracheoesophageal abnormalities. Duodenal obstruction due to annular pancreas or duodenal atresia occurs in a small percentage of patients. Malrotation with Ladd bands and Hirschsprung disease can be associated. The association of imperforate anus and vertebral anomalies like lumbosacral anomalies and spinal dysraphism are seen more in higher malformations. Higher incidence of spinal malformations is seen in children even with low malformations. The most common type of dysraphism is tethered spinal cord, which is present in as many as $35 \%$ of patients. The normal spinal cord terminates between the first and second lumbar vertebral bodies. In patients with a tethered spinal cord, the cord ends lower in the lumbar spine. Cord lipomas and syringohydromyelia are also common. All lumbosacral spinal malformations negatively affect the child's prognosis with respect to urinary and faecal incontinence, Currarino triad of sacral defect, presacral mass and imperforate anus. Urinary anomalies are more common in patients with more complex lesions around 30 percent. Mild hydronephrosis is the most common abnormal ultrasonography finding. Vesicoureteric reflux is also a frequent finding, followed by renal agenesis and dysplasia. Undescended testes reportedly occurs in 3\% - 15\% of males. Bicornuate uterus and uterus didelphys occur in $25 \%$ of female patients with imperforate anus. A vaginal septum is the most common vaginal abnormality and is seen in as many as one-half of girls born with a cloacal malformation. Vaginal duplication and agenesis have also been reported. Vaginal agenesis may be associated with ipsilateral absent ovary and kidney.

\section{Investigations}

CBC count, blood typing and screening and serum electrolyte levels should be measured in all children with imperforate anus who require operation. Urinalysis should be performed to determine the presence of a rectourinary fistula in all cases, in which the diagnosis cannot be made based solely on the physical examination findings. X-ray lumbosacral spine,(8) two views of the sacrum, postero-anterior and lateral should be obtained to measure sacral ratios and to look for sacral defects, hemivertebrae and presacral masses. This should be performed before surgery.

\section{Abdominal Ultrasound(9)}

This study is specifically used to examine the genitourinary tract and to look for any other masses. Hydronephrosis, hydrocolpos, presacral mass, abdominal mass or any similar finding can profoundly affect management. This study should be performed before surgery and must be repeated after 72 hours, because early ultrasonography findings may be insufficient to rule out hydronephrosis due to vesicoureteral reflux. Spinal ultrasonography or MRI may be required.

\section{Lateral Pelvic Radiography at 24 Hours}

Children who could not be diagnosed based solely on physical examination findings traditionally underwent invertogram, which consisted of holding the baby upside down and using lateral radiography to observe the level of gas in the distal rectum. A similar but more humane approach is to wait 24 hours after birth to observe for possible maximal pelvic pouch distension and then to use cross-table lateral pelvic radiography with a radio-opaque marker on the anal dimple with the child in the prone position and the hips slightly raised. If the pouch is observed within $1 \mathrm{~cm}$ of the marker, some surgeons offer primary repair without colostomy. For pouches farther than $1 \mathrm{~cm}$, colostomy is performed. This 1 $\mathrm{cm}$ guideline has been validated only using radiographic measurements and is not directly translatable for measurements made using ultrasonography. Perineal ultrasonography may be useful to measure skin to bowel end length. Augmented pressure distal colostography: This is the single most important diagnostic test used to clarify the anatomy in all children with malformations to plan the surgical approach for staged procedure, micturating cystourethrography and MRI may be useful.

Wingspread classification- Malformations at or above the levator muscle complex were defined as high anomalies. Infralevator lesions were termed low and were considered simpler and were associated with better prognosis.

\begin{tabular}{|c|c|}
\hline \multicolumn{2}{|c|}{ Wingspread classification (1986) } \\
\hline Female & Male \\
\hline \multicolumn{2}{|r|}{ High } \\
\hline $\begin{array}{ll}\text { Anorectal agenesis } \\
\text { a }\end{array}$ & \multirow{4}{*}{$\begin{array}{l}\text { Anorectal } \\
\text { Rectoprostatic } \\
\text { fistula } \\
\text { Rectal atresia }\end{array}$} \\
\hline fistula No fistula & \\
\hline Rectal atresia & \\
\hline & \\
\hline \multicolumn{2}{|l|}{$\begin{array}{lll}\text { Intermediate } & \text { Rectovaginal } & \text { fistula }\end{array}$} \\
\hline \multirow[t]{2}{*}{ Rectovestibular fistula Anal agenesis } & \multirow{2}{*}{$\begin{array}{l}\text { Intermediate Bulbar fistula } \\
\text { Anal agenesis } \\
\end{array}$} \\
\hline & \\
\hline \multicolumn{2}{|l|}{ Low } \\
\hline $\begin{array}{ll}\text { Anovestibular } & \text { fistula }\end{array}$ & Low \\
\hline fistula Anal stenosis & \multirow{2}{*}{$\begin{array}{lcc}\text { Anocutaneous } & \text { fistula } & \text { Anal } \\
\text { stenosis } & & \\
\end{array}$} \\
\hline stenosis & \\
\hline Rare malformations & \multirow[b]{2}{*}{ Rare malformations } \\
\hline & \\
\hline
\end{tabular}

\begin{tabular}{|c|c|}
\hline Males & Females \\
\hline Perineal fistula & Perineal fistula \\
\hline Rectourethral fistula & Vestibular fistula \\
\hline Bulbar & Persistent cloaca \\
\hline Prostatic & $<3 \mathrm{~cm}$ common channel \\
\hline Rectovesical (bladder neck) & $>3 \mathrm{~cm}$ common channel \\
\hline $\begin{array}{c}\text { Imperforate anus without } \\
\text { fistula }\end{array}$ & $\begin{array}{c}\text { Imperforate anus without } \\
\text { fistula }\end{array}$ \\
\hline \multicolumn{2}{|c|}{ Rectal atresia } \\
\hline \multicolumn{2}{|c|}{ Pena's Classification 1995 } \\
\hline \multicolumn{2}{|c}{} \\
\hline
\end{tabular}

\begin{tabular}{|c|c|}
\hline Major Clinical Groups & Rare/ Regional Variants \\
\hline Perineal (cutaneous) fistula & Pouch colon \\
\hline Rectourethral fistula & \\
Bulbar & Rectal atresia/ stenosis \\
Prostatic \\
Bladder neck & \\
\hline Vestibular fistula & Rectovaginal fistula \\
\hline Cloaca & H-type fistula \\
\hline No fistula & Others \\
\hline Anal stenosis & \\
\hline \multicolumn{2}{|c|}{ Krickenbeck Classification (2005) } \\
\hline
\end{tabular}


Information obtained from the posterior sagittal approach has led to an anatomic classification that lists malformations based on their specific anatomy. The following is a list of the most common malformations: Recent trends are towards minimally invasive and single stage procedures.(10)

1. Perineal Fistula- This malformation is associated with good prognosis, occurs in either sex and involves a closed anus with a small connection opening on the perineal body. May have small loop of skin at the anal opening that resembles a bucket-handle. This is pathognomonic for perineal fistula. Some boys may have no visible perineal opening but may accumulate mucous or meconium in the fistula, which can extend up the median raphe of the scrotum and resembles a black cord (meconium) or a string of pearls (mucous). The anus of an average-term newborn should be approximately 12 $\mathrm{mm}$, may present as anal stenosis.

2. Bulbar Urethral Fistula- Relatively common in boys.(11) No fistula visible. Urinalysis often shows meconium. Colostomy is essential to relieve obstruction.

3. Prostatic Urethral Fistula- Seen in boys, rarer than bulbar fistula and carries a poorer prognosis.

4. Bladder-Neck Fistula- Rare and is seen in boys ( $10 \%$ of males), carries a very poor prognosis. This fistula is best approached abdominally. Colostomy is essential as initial management.

5. Absent Fistula- Can occur in either sex, associated with good prognosis, commonly associated with trisomy 21.(12) This malformation is somewhat rare and diagnosis is primarily by exclusion. If the pelvic rectal pouch is within $1 \mathrm{~cm}$ of the anal dimple, a primary pullthrough may be performed.

6. Vestibular Fistula- This malformation is associated with good prognosis and is easily diagnosed upon physical examination based on the appearance of a small opening at the posterior aspect of the vestibule. The opening is external to the hymen and is therefore not vaginal. True solitary congenital rectovaginal fistula is exceedingly rare; can be treated by diverting colostomy or repair this malformation primarily in the newborn period without using colostomy or later by anal transposition or posterior sagittal anorectoplasty.

7. Cloaca- Persistent cloaca with spectrum of defects including the presence of a common channel that incorporates the urethra, vagina and rectum in female. The length of the common channel correlates with complexity and prognosis. Shorter channels $(<3 \mathrm{~cm})$ have fewer associated malformations and carry a better prognosis. Longer channels have more complex malformations and poorer prognosis; $40 \%-50 \%$ have two hemivaginas and many have hydrocolpos. Easily diagnosed by observing a solitary perineal orifice associated with very small-appearing labia. All children with cloacae should undergo colostomy shortly after birth.

8. Cloacal Exstrophy- Extremely rare malformation, can occur in either sex, but is most common in boys. The classic form is devastatingly complex. Affected children have an omphalocoele and a large extrophied cloacal plate on their lower abdominal wall. They have two hemibladders separated by an intestinal plate, often with prolapsed terminal ileum that proceeds distally to include an extrophied urethral plate flanked by two hemiphallic or hemiclitoral structures. All children with cloacal exstrophy have some degree of pubic symphysis diastasis and may have a spinal malformation, most commonly myelocystocele.

\section{MATERIALS AND METHODS}

\section{Study Design}

Retrospective record based study. We received 690 patients during July 2005 to July 2017 to our department over 12-year period as first admission. Out of 690,478 are males (69.3\%) and $212(30.7 \%)$ are females. ${ }^{(13)}$

\section{Boys}

191 male children out of 478 has low anorectal anomalies by clinically and radiologically as bulging anal region, anocutaneous fistula or bucket-handle deformity. All these children underwent cut-back anoplasty on the same day. Another 244 male children out of 478 presented with meconium per urethra, crowded perineum and high or intermediate anomaly on x-ray underwent diverting colostomy; 12 male children who had associated oesophageal atresia with tracheoesophageal fistula underwent thoracotomy repair and diverting colostomy; 18 male children had pouch colon,(14) underwent laparotomy, excision of pouch colon, end colostomy or ileostomy; 7 male children had cloacal exstrophy, underwent ileostomy and repair of hemibladders. Six male children underwent primary posterior sagittal anorectoplasty. Total diverting colostomies are 281.

\begin{tabular}{|c|c|c|c|}
\hline $\begin{array}{c}\text { Males } \\
\text { (Newborn) }\end{array}$ & No. & Type & Procedure \\
\hline $\begin{array}{c}\text { Total } \\
(69 / 690 \\
\text { Males }\end{array}$ & $\begin{array}{c}191 / 478 \\
(39.9 \%)\end{array}$ & $\begin{array}{c}\text { Low anorectal } \\
\text { anomalies } \\
(39.9 \% \text { of males) }\end{array}$ & $\begin{array}{c}\text { Cut back } \\
\text { anoplasty }\end{array}$ \\
\hline & $\begin{array}{c}244 / 478 \\
(51.0 \%)\end{array}$ & $\begin{array}{c}\text { Rectourethral } \\
\text { fistulas }\end{array}$ & $\begin{array}{c}\text { Diverting } \\
\text { colostomy }\end{array}$ \\
\hline & $\begin{array}{c}12 / 478 \\
(2.5 \%)\end{array}$ & $\begin{array}{c}\text { Oesophageal } \\
\text { atresia with TEF } \\
\text { with rectourethral } \\
\text { fistulas }\end{array}$ & $\begin{array}{c}\text { Thoracotomy } \\
\text { and repair + } \\
\text { diverting } \\
\text { colostomy }\end{array}$ \\
\hline & $\begin{array}{c}18 / 478) \\
\text { Anorectal Anomalies in Male Newborns }\end{array}$ & $\begin{array}{c}\text { Pouch colon with } \\
\text { rectourethral } \\
\text { fistulas }\end{array}$ & $\begin{array}{c}\text { Laparotomy, } \\
\text { excision of } \\
\text { pouch colon, } \\
\text { end colostomy } \\
\text { or ileostomy }\end{array}$ \\
\hline & $\begin{array}{c}7 / 478 \\
(1.4 \%)\end{array}$ & $\begin{array}{c}\text { Cloacal exstrophy } \\
\text { 6/478 }\end{array}$ & $\begin{array}{c}\text { Ileostomy and } \\
\text { repair of } \\
\text { hemibladders }\end{array}$ \\
\hline & $\begin{array}{c}\text { Total diverting/ } \\
\text { end colostomies } \\
\text { or ileostomies= } \\
281 / 478 \text { (58.7\%) }\end{array}$ & $\begin{array}{c}\text { Primary } \\
\text { posterior } \\
\text { sagittal } \\
\text { anorectoplasty }\end{array}$ \\
\hline \\
\hline
\end{tabular}




\section{Girls}

Total girls 212, 14 girls had no anal or vestibular anal opening. No meconium at perineum with low anomaly, 4 had anal stenosis. All 18 girls underwent anoplasty. 36 girls underwent diverting colostomy for high anomaly. 18 children had associated oesophageal atresia with tracheoesophageal fistula underwent thoracotomy repair and diverting colostomy. Two girl children had pouch colon, underwent laparotomy, excision of pouch colon, end colostomy one or ileostomy one. 18 girls had cloacal anomalies, 6 patients had undergone primary posterior sagittal anorectoplasty (PSARP). 108 girls with vestibular anus on regular dilatation plan till PSARP or anal transposition; 6 girls with ectopic anterior anus on regular dilatation plan till PSARP or anal transposition.

\begin{tabular}{|c|c|c|c|}
\hline $\begin{array}{c}\text { Girls } \\
\text { (Newborn) } \\
212 / 690 \\
(30.7 \%) \\
\text { of Total } \\
\text { ARMs }\end{array}$ & Nos. & Type & Procedure \\
\hline & \begin{tabular}{|c|}
$14 / 212$ \\
girls $(6.6 \%)$
\end{tabular} & $\begin{array}{l}\text { No opening, } \\
\text { low anomaly }\end{array}$ & Anoplasty \\
\hline & $\begin{array}{c}4 / 212 \text { girls } \\
(1.8 \%)\end{array}$ & $\begin{array}{l}\text { Anal stenosis } \\
\text { low anomaly }\end{array}$ & Anoplasty \\
\hline & $\begin{array}{c}36 / 212 \text { girls } \\
(16.9 \%)\end{array}$ & $\begin{array}{l}\text { High ARM or } \\
\text { with difficulty } \\
\text { for regular } \\
\text { dilatation } \\
\end{array}$ & $\begin{array}{l}\text { Diverting } \\
\text { colostomy }\end{array}$ \\
\hline & $\begin{array}{c}18 / 212 \text { girls } \\
(8.4 \%)\end{array}$ & $\begin{array}{l}\text { High anomaly } \\
\text { with } \\
\text { oesophageal } \\
\text { atresia +/- } \\
\text { TEF } \\
\end{array}$ & $\begin{array}{l}\text { Thoracotomy } \\
\text { repair and } \\
\text { diverting } \\
\text { colostomy }\end{array}$ \\
\hline & $\begin{array}{c}2 / 212 \text { girls } \\
(0.9 \%)\end{array}$ & Pouch colon & $\begin{array}{c}\text { Laparotomy, } \\
\text { excision of pouch } \\
\text { colon, end } \\
\text { colostomy (1) or } \\
\text { ileostomy (1) }\end{array}$ \\
\hline & $\begin{array}{c}18 / 212 \text { girls } \\
(8.4 \%)\end{array}$ & $\begin{array}{c}\text { Cloacal } \\
\text { anomalies }\end{array}$ & $\begin{array}{l}\text { Diverting } \\
\text { colostomy }\end{array}$ \\
\hline & $\begin{array}{c}\text { 6/212 girls } \\
(2.8 \%)\end{array}$ & & $\begin{array}{c}\text { Primary posterior } \\
\text { sagittal } \\
\text { anorectoplasty }\end{array}$ \\
\hline & $\begin{array}{l}108 / 212 \\
\text { girls } \\
(50.9 \%)\end{array}$ & $\begin{array}{l}\text { Vestibular } \\
\text { anus }\end{array}$ & $\begin{array}{c}\text { Regular dilatation } \\
\text { plan till weight } \\
\text { gain for PSARP or } \\
\text { anal transposition }\end{array}$ \\
\hline & $\begin{array}{c}6 / 212 \text { girls } \\
(2.8 \%)\end{array}$ & $\begin{array}{c}\text { Ectopic } \\
\text { anterior anus }\end{array}$ & $\begin{array}{l}\text { Regular dilatation } \\
\text { plan till weight } \\
\text { gain for PSARP or } \\
\text { anal transposition }\end{array}$ \\
\hline & & & $\begin{array}{c}18 \text { anoplasty, } 74 \\
\text { diverting } \\
\text { colostomies / } \\
\text { stoma, } 6 \text { primary } \\
\text { pull through; } 114 \\
\text { wait for weight } \\
\text { gain }\end{array}$ \\
\hline
\end{tabular}

We followed up all patients for complications and for detection of associated abnormalities as well as for planning the next stage of operations.

Procedure done as $2^{\text {nd }}$ stage or single stage after weight gain in 294 patients. Abdominoperineal pull-through(15) was done in 18 male patients and in 2 female patients. Anal transposition was done for vestibular anus in females as single stage without prior colostomy in 84 patients. Anal transposition was done for ectopic anterior anus in females as single stage without prior colostomy in 6 patients. PSARP was done for vestibular anus in females as second stage with prior colostomy in 24 patients; PSARP for males as second stage with prior colostomy in 160 patients.

\begin{tabular}{|c|c|c|c|}
\hline 1 & $\begin{array}{l}\text { Abdominoperineal } \\
\text { pull through }\end{array}$ & \begin{tabular}{|c|}
20 of total 690 \\
boys (17) and \\
girls $(3)=(2.8 \%)$
\end{tabular} & \\
\hline 2 & $\begin{array}{c}\text { Anal transposition as } \\
\text { single stage without } \\
\text { prior colostomy in } 84 \\
\text { girl patients }\end{array}$ & $\begin{array}{l}84 / 690 \\
(12.1 \%)\end{array}$ & \\
\hline 3 & $\begin{array}{c}\text { Anal transposition } \\
\text { ectopic anterior anus } \\
\text { in females as single } \\
\text { stage }\end{array}$ & $6 / 690(0.8 \%)$ & \\
\hline 4 & $\begin{array}{l}\text { PSARP was done for } \\
\text { vestibular anus in } \\
\text { females as second } \\
\text { stage with prior } \\
\text { colostomy }\end{array}$ & $24 / 690(3.4 \%)$ & \\
\hline 5 & $\begin{array}{c}\text { PSARP for males as } \\
\text { second stage with } \\
\text { prior colostomy }\end{array}$ & $\begin{array}{l}160 / 690 \\
(23.1 \%)\end{array}$ & $\begin{array}{c}=\text { Total } \\
294 / 690 \\
(42.6 \%)\end{array}$ \\
\hline & \multicolumn{3}{|c|}{$\begin{array}{c}\text { Procedure done as } 2^{\text {nd }} \text { Stage or Single Stage } \\
\text { after Weight Gain }\end{array}$} \\
\hline
\end{tabular}

\section{RESULTS}

Deaths in newborn period $42(42 / 690=6.08 \%)$. After newborn period, deaths $12(12 / 294=4.08 \%)$; constipation 18 patients in anoplasty group 18/209 (8.6\%), 39 patients in non-anoplasty group $(39 / 306=12.7 \%)$; incontinence- 5 patients in anoplasty group $(5 / 209=2.3 \%)$ and 67 patients in non-anoplasty group $(67 / 306=21.8 \%)$. Stenosis was seen in 6 patients in anoplasty group $(6 / 209=2.87 \%), 17$ patients in non-anoplasty group $(17 / 306=5.5 \%)$. Retraction was seen in 2 patients in anoplasty group $(2 / 209=0.95 \%)$ and 12 patients in non-anoplasty group $(12 / 306=3.92 \%)$. Prolapse of stoma was seen in 12 patients in non-anoplasty group $(12 / 306=3.9 \%)$. Urinary incontinence was noted in 14 patients in non-anoplasty group $(14 / 306=4.57 \%)$, urethral stricture or complete stenosis in 4 patients in non-anoplasty group $(4 / 306=1.3 \%)$. Redo procedures done in 8 patients in non-anoplasty group as neo anus retracted with ischaemic necrosis of pulled bowl $(8 / 306=2.6 \%)$. Permanent colostomy was done for neurogenic defects in two patients in nonanoplasty group $(2 / 306=0.6 \%)$. 


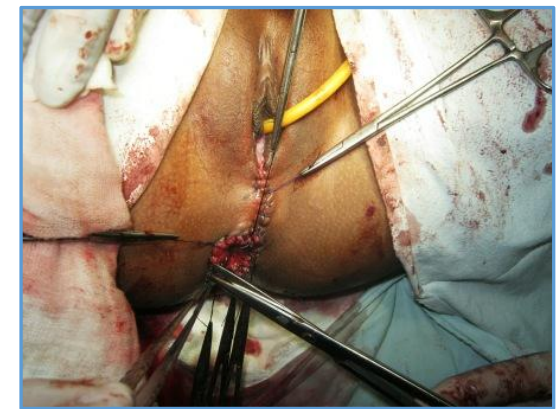

Anal Transposition for Vestibular Anus

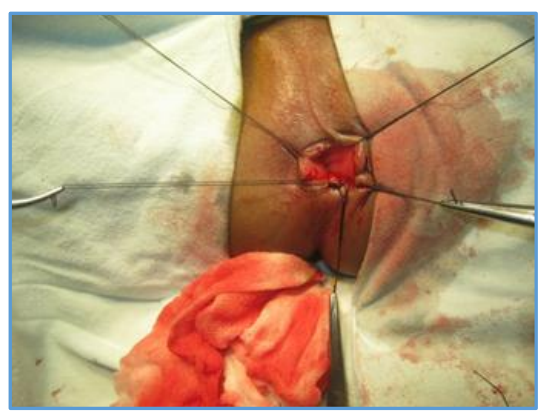

Anoplasty for Low Anomalies

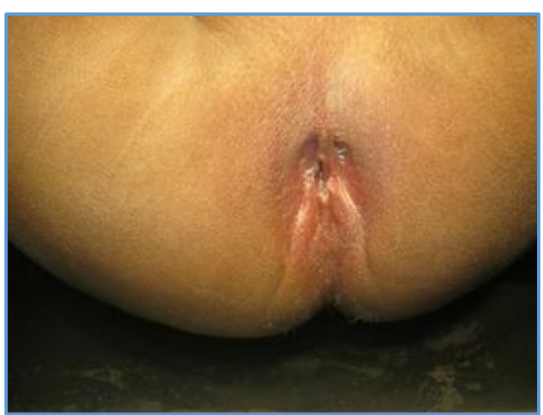

Bucket-Handle Deformity Low

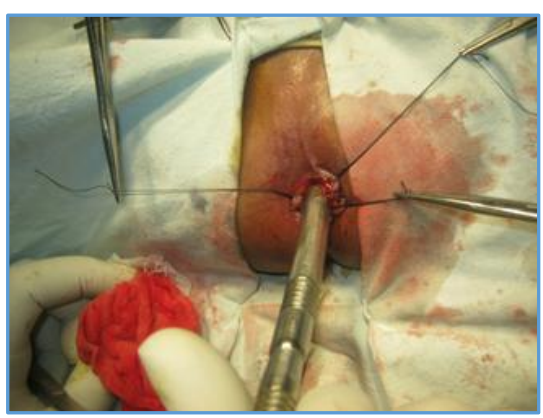

Calibration of Anal Size

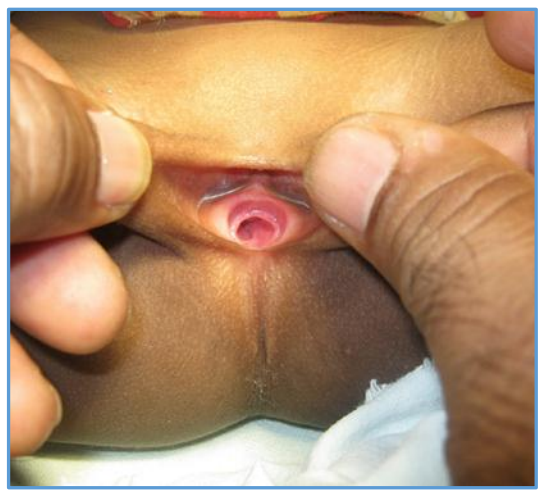

Cloaca

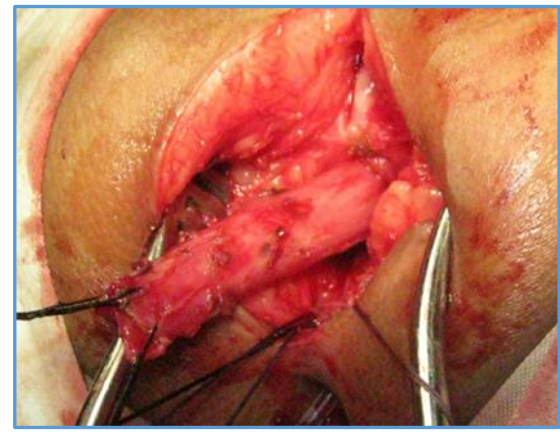

Mobilised Rectum in PSARP

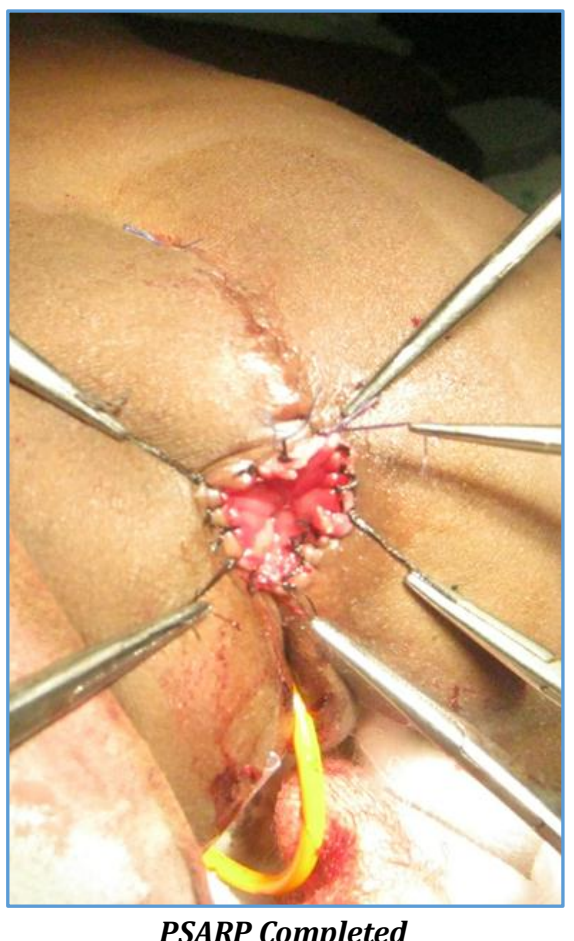

PSARP Completed

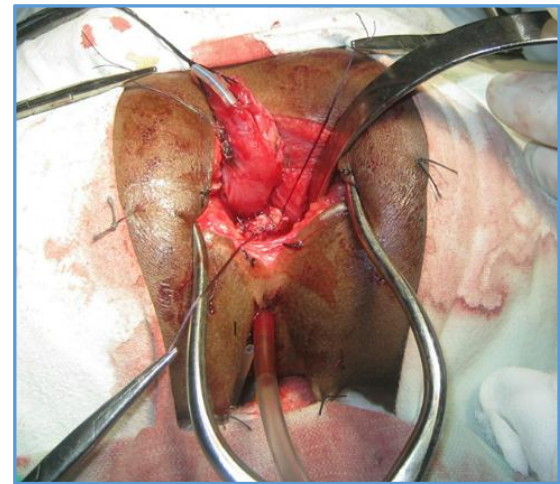

PSARP for Cloaca

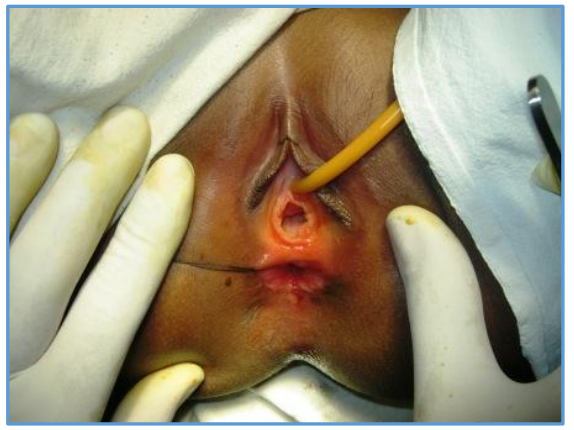

Vestibular Anus 


\section{DISCUSSION}

Total patients are 690 during 12-year period; 478 are males and 212 are females. Sex ratio is nearly equal in literature. In our institution male predominance was noted, may be due to ignorance, social stigma or taboo or sex discrimination. Most of our patients presented to us within first two days of life. Low ARM is managed with anoplasty. Breast feeds were given on $2^{\text {nd }}$ postop day if no distention, progressive anal dilatation by Hegar dilators after two weeks. Diverting colostomy group are under regular follow-up, around $6-10 \mathrm{~kg}$ weight gain, PSARP or abdominoperineal pull-through done and colostomy closure after three months of $2^{\text {nd }}$ stage. Vestibular anus patients managed with dilatation by Hegar dilators daily till 8 - $10 \mathrm{~kg}$ weight, followed by anal transposition or PSARP done.

\section{CONCLUSION}

Most of the low anomalies and majority high anomalies have reasonably acceptable results. There has been a great shift in approach to these patients, which involves holistic approach to the syndrome of anorectal malformations with a long-term goal of achievement of complete faecal and urinary continence with good quality of life. Continence and constipation improves with age.

\section{REFERENCES}

[1] Levitt MA, Pena A. Imperforate anus and cloacal malformations. In: Holcomb GW III, Murphy JP, (eds). Ashcraft's pediatric surgery. $5^{\text {th }}$ edn. Philadelphia, PA: Saunders Elsevier, 2010:468-90.

[2] Calda P, Hašlík L, Žižka Z, et al. Prenatal diagnosis and neonatal management of anorectal malformation-a case report. Prague Medical Report/Vol. 110 (2009) No. 3, p. 255-60.

[3] Sharma SS, Ansari AA, Shukla K, et al. A retrospective (2004-2013) and prospective (2014-2015) study of new born with special reference to anorectal malformations over a period of 10 years at a tertiary care centre. Int J Res Med Sci 2016;4(4):1005-9.
[4] Belloni E, Martucciello G, Verderio D, et al. Involvement of the HLXB9 homeobox gene in currarino syndrome. Am J Hum Genet 2000;66(1):312-9.

[5] Kluth D. Embryology of anorectal malformations. Semin Pediatr Surg 2010;19(3):201-8.

[6] Kluth D, Lambrecht W. Current concepts in the embryology of anorectal malformations. Semin Pediatr Surg 1997;6(4):180-6.

[7] Ratan SK, Rattan KN, Pandey RM, et al. Associated congenital anomalies in patients with anorectal malformations--a need for developing a uniform practical approach. J Pediatr Surg 2004;39(11):170611.

[8] McHugh K. The role of radiology in children with anorectal anomalies; with particular emphasis on MRI. Eur J Radiol 1998;26(2):194-9.

[9] Le Bayon AG, Carpentier E, Boscq M, et al. Imaging of anorectal malformations in the neonatal period.J Radiol 2010;91(4):475-83.

[10] Kimura O, Iwai N, Sasaki Y, et al. Laparoscopic versus open abdominoperineal rectoplasty for infants with high-type anorectal malformation.J Pediatr Surg 2010;45(12):2390-3.

[11] Bischoff A, Levitt MA, Peña A. Laparoscopy and its use in the repair of anorectal malformations. J Pediatr Surg 2011;46(8):1609-17.

[12] Stephens FD. Congenital imperforated rectum, rectourethral and recto-vaginal fistulae. Aust $\mathrm{N} \mathrm{Z} \mathrm{J}$ Surg 1953;22(3):161-72.

[13] Iwai N, Yanagihara J, Tokiwa K, et al. Results of surgical correction of anorectal malformations. A 1030 year follow-up. Ann Surg 1988;207(2):219-22.

[14] Narasimharao KL, Yadav K, Mitra SK, et al. Congenital short colon with imperforate anus (pouch colon syndrome). Ann Pediatr Surg 1984;1:159-67.

[15] Langemeijer RA, Molenaar JC. Continence after posterior sagittal anorectoplasty. J Pediatr Surg 1991;26(5):587-90. 